\title{
7 Ukraine: The quest for democratization between Europe and Russia
}

\author{
Roman Petrov and Oleksander Serdyuk
}

\section{Introduction}

The European Union (EU) enlargement not only shaped the modern political and economic appearance of the expanded Europe, but also tested the democratic legitimacy of the integration machinery, since it assumed the importation of the vast European democratic heritage into candidate countries. Gradually, results of this endeavor were reflected in member states and candidate countries and in 'non-applicant' countries, such as Ukraine, which associate themselves with the enlarged Europe and have thereby embarked upon the drift away from the old legacy of Socialism.

Among the countries which are studied in this book, Ukraine is distinguished by the strongest communist legacy, a dubious honor. The Ukrainian Soviet Socialist Republic was one of the most important political, military and industrial bastions of the USSR. In fact, Ukraine had for many years enjoyed a dominant political position in Moscow among other Soviet republics. Two General Secretaries of the Soviet Communist Party came from Ukraine. The process of democratization in Ukraine started shortly after gaining independence in 1991, and was supported by the newly emerging political elite, which mainly included former leaders of the Ukrainian Party (Kravchuk) and recognized leaders of the National Movement (Rukh). As a priority, Ukraine set a political objective of integration into international political and economic structures and, consequently, the achievement of membership of the Council of Europe and the EU. Once the Council of Europe and the EU established criteria for achieving that goal, substantive attempts were launched to prove the conformity of Ukraine's political and legal systems in the spheres of democracy and human rights. However, the efforts of change agents in the country have met strenuous resistance from veto players, who defended their privileged political and economic positions at the expense of democratic reforms and the rule of law. The fact that the EU never endorsed the possibility of Ukraine becoming a full member state further undermined the chances of change agents gathering sufficient strength to promote deep liberalization changes in Ukrainian society. The EU policy of strict conditionality without any prospect of membership hampered 
rule adoption and rule implementation of western democratic values in Ukraine. At the same time veto players in Ukraine could credibly advocate alternatives to EU integration, particularly closer alignment with a resurgent Russia.

The objective of this chapter is to analyze democratic rule of law reforms in Ukraine in the five sectors, and to evaluate whether and to what degree, if at all, external actors - and especially the EU - has managed to affect rule of law reforms in Ukraine, using the EUCLIDA analytical framework. We will scrutinize the positive and negative role of international actors in the process of rule adoption, rule implementation, and rule internalization of democratic rule of law. Attention will be paid to specific features of the Ukrainian political and legal environment which imply certain specifications in the implementation of democratic rule of law standards in Ukraine. It is argued that the major specification is the historical and ethnic split of the Ukrainian nation, which led to never-ending conflict between change agents and veto players on the main issues of democratic rule of law reforms in Ukraine. The time frame of our analysis embraces the period from Ukrainian independence in 1991 to the post-Orange Revolution era in 2004-06. The remainder of the introduction will present a general overview of the Ukrainian political scene since 1991 with a focus on the main political actors who form change agents and veto players' camps. The other sections of the chapter will discuss the democratic rule of law implementation in Ukraine in line with the EUCLIDA model (see Chapter 2, in this volume).

Modern independent Ukraine inherited many political, economic and ethnic problems from the former USSR. From the early days of its history until today Ukraine has been sharply divided by diverging political and ethnic influences. Such divergence implies political and economic imbalances, which have constantly to be kept in right equilibrium to maintain the political stability and peaceful coexistence of Ukraine's multinational society.

From the early days of independence deep geographical divisions between the west and the east of Ukraine have become apparent. Such divisions have been engendered by Ukraine's complex history. Representatives of various Russian-speaking national minorities populate the industrial east of Ukraine. The Autonomous Republic of Crimea maintains strong political and cultural ties with the Russian Federation (until 1963 Crimea was part of the Russian Federation). The western areas of Ukraine experienced strong political and cultural influences from Poland and the former Austrian-Hungarian Empire in the nineteenth and early twentieth centuries. Consequently, the political life of modern Ukraine reflects a historical kaleidoscope of pro-west and pro-east preferences and traditions of multinational Ukraine.

From the early 1990s the Communist Party gained popular support in the industrial Russian-speaking east of Ukraine (gaining 20 percent of the popular vote in the 1994 parliamentary elections and 25 percent in 1998). The pro-nationalistic party 'Rukh' received a significant share of the electorate in the rural Ukrainian-speaking west (5 percent of the 1994 parliamentary election votes and 10 percent of those in 1998). To some degree, the 2002 
parliamentary elections highlighted the depth of this geographical split, by bringing a wider range of political parties into the Verkhovna Rada. Change agents grouped around the pro-European 'Our Ukraine' Party (which won 30 percent of seats), headed by former Prime Minister Viktor Yuschenko and the Yulia Tymoshenko Bloc - 'BUT' (5 percent of seats). Veto players managed to create a political coalition around the pro-Russian president party "For United Ukraine" (25 percent of seats), Communist Party (15 percent), and Social Democratic Party ( 5 percent). ${ }^{1}$ Such a strong representation of nonliberals inhibited the long awaited acceleration of the rule adoption and implementation/internalization of internationally recognized democratic values in Ukraine. The veto players' coalition supported President Kuchma's 'multivector foreign policy' directed at closer integration both with the EU and with former Soviet republics. The EU and other international actors applied the policy of conditionality towards Ukraine, and, therefore, constantly questioned the credibility of the Ukrainian government by emphasizing its poor record in human rights protection and in the fight against corruption. The still unsolved killing of the opposition journalist Georgiy Gongadze demonstrated the low standards of human rights protection in Ukraine.

However, the kaleidoscope of the ruling elites in Ukrainian society has drastically changed since the Orange Revolution in December 2004. On the one hand, this revolution raised popular concern not only about such issues as the fight against corruption and economic recovery, but also about more widespread and effective endorsement of European liberal political values and alignment with EU rules in particular. On the other hand, the Orange Revolution has considerably shaken the fragile balance between the constantly diverging west and east of Ukraine.

From the outset, the newly elected President Victor Yuschenko and his government, headed by Prime Minister Yulia Tymoshenko, endeavored to eliminate the influence of veto players by making more than 17,000 new appointments within the executive, security agencies and civil services of people who claimed support for the pro-western policy of the Ukrainian government. Soon after the victory of the Orange Revolution the coalition of veto players in the Verkhovna Rada collapsed. Many of the former coalition members fled to the change agents' blocs 'Our Ukraine' and 'BUT'. Major security positions were distributed between political leaders who took active part in the Revolution and openly declared their pro-western views. People with a strong pro-western orientation filled the civil service as well. However, newly appointed pro-western top executives rarely managed to employ competent civil servants to replace experienced members of the old administration who retired or were dismissed. As a result, the efficiency of the executive branch of power immediately declined in the aftermath of the Orange Revolution. The position of the government was considerably strengthened by the signing of the EU-Ukraine Action Plan on 21 February 2005 in Brussels. The Plan was presented to the Ukrainian public as a step forward in relations between the EU and Ukraine, and as an expression of the EU's support for democratic and market reforms in the post-Orange Revolution Ukraine. 


\section{Roman Petrov and Oleksander Serdyuk}

However, the Action Plan was not welcomed by all political parties in Ukraine. The fact that it did not provide any prospect of Ukraine's membership of the EU was loudly criticized by some veto players. ${ }^{2}$ Furthermore, President Yuschenko and the Orange Revolution government strongly advocated the need for Ukraine to join NATO as a prerequisite for full EU membership. However, these initiatives have not been welcomed, especially in the pro-Russian east of Ukraine. As a result the issue of NATO membership decreased support for further integration of Ukraine into the EU and deepened the split in the country between the west and the east. ${ }^{3}$

The Orange Revolution also affected the balance of external influence on processes in Ukraine. The 2006 parliamentary elections sharpened the ever-present conflict between pro- and anti-western elites in Ukraine. These elections reflected new problems in Ukrainian society. Continuing standstill in economic growth and a worsening of political and economic relations with Russia, against the background of a rather lukewarm reception by the EU to Ukrainian integration initiatives, led to dissatisfaction among the Ukrainian public with the Orange Revolution change agents. ${ }^{4}$ Pro-western circles became more and more convinced that the EU is leaving Ukraine all alone with Russia, at a time when the latter is becoming increasingly authoritarian domestically, and possessive of the former territories of the USSR, Russia has been trying to increase its influence over Ukraine, by using first of all the 'gas factor' and making political and business elites doubt the necessity of pro-European orientation.

The 2006 parliamentary elections opened old wounds and divided Ukraine geographically, as had happened in the aftermath of Ukrainian independence. As a result of these elections veto players gained a significant share of seats in the Verkhovna Rada (the Party of Regions gained 32 percent of seats and the unreconstructed Communist Party 3 percent). Change agents grouped around the "democratic coalition", which comprised 'BUT' (26 percent), 'Our Ukraine' (16 percent) and the Socialist Party ( 5 percent). However, due to internal disagreements and power ambitions, change agents missed the opportunity to form the majority coalition for three months after the elections. This situation led to political and economic instability in the country and threatened the second parliamentary elections. As a result, the "democratic coalition" collapsed in July 2006 after the Socialist Party jointed the illiberal camp and initiated the building of the 'anti-crisis coalition' with the Party of Regions and the Communist Party in summer 2006.

The change in the political balance in the Verkhovna Rada and the adoption of new laws, which transferred considerable powers from the President of Ukraine to the Prime Minister with the so-called 'Constitutional reform' led to a serious constitutional crisis in April 2007. On 2 April 2007 President V. Yuschenko disbanded the Verkhovna Rada and called new parliamentary elections. After the prolonged political standoff and the risk of nationwide disturbances, the leaders of the opposing political camps decided to prevent any possibility of further escalation of the conflict and agreed to 
conduct new parliamentary elections in September 2007.5 The outcome of these elections served to further emphasize the depth of the political cleavage between national elites, which was not only maintained, but also deepened by the ineffectiveness of political institutions and the absence of traditions of parliamentarianism and democratic politics. In spite of having a relative majority in the Verkhovna Rada (45.2 percent, but, with a majority of only two seats), pro-Western parties ('BUT' and 'Nasha Ukraina') were still unable to form an effective Parliamentary coalition. In fact, their action has been constantly blocked by the Party of Regions, which is trying to preserve its influence in the country by manipulating the constitutional procedures. After the elections it also became evident that the narrow-minded policies supported by a few politicians and political forces cannot be kept back by any restraining institutional mechanism. This forms the systematic drawback of the model of parliamentary republic which they tried to carry out in Ukraine with the Constitutional reform. In such a situation of conflict, the actual influence of external actors decreases significantly, and previous reforms that set up the basis for developing of democratic standards are called into question. ${ }^{6}$

\section{Protection of civil freedoms and political rights}

One can argue that protection of civil freedoms and political rights was always guaranteed by the constitutions of the USSR and Soviet Ukraine. In these documents the scope of civil freedoms and political rights was specified and proclaimed as an attribute of real democracy. However, the declarative character of these provisions and the lack of correspondence with the realities of public life were perceived with displeasure by a significant part of Ukrainian society. In the time of political repressions before Gorbachov's perestroika, the issue of human rights acquired a particularly important value. In the opinion of political dissidents the civil freedoms and political rights proclaimed in the constitutions of the USSR and Soviet Ukraine were engendered from western democratic standards of the supremacy of human rights. Public criticism of the fictitiousness of human rights declared, and the impossibility of their practical realization in the conditions of the Soviet regime, was one of the reasons for popular dislike of the Soviet regime, which collapsed in 1991.

Newly independent Ukraine initiated a political dialogue with the Council of Europe in 1992. Change agents, who included pro-western political elites (mainly opposition political parties), with a clearly defined agenda for democratic political system based on international standards, advocated the idea of Ukraine moving beyond general political declarations on democratic choice and the priority of human rights and launching concrete steps to ensure practical implementation of these values. The position of the Council of Europe became a determining external factor in these processes in Ukraine. In 1995, after joining the Council of Europe, Ukraine took up obligations which provided real tools for protection for civil freedoms and political 


\section{Roman Petrov and Oleksander Serdyuk}

rights in the country. ${ }^{7}$ In 1998 Ukraine agreed to political conditionality set by the EU under the framework of the EU-Ukraine Partnership and Cooperation Agreement (PCA). This agreement provided that the attainment of economic objectives (free trade area between Ukraine and the EU) was dependent on the success of economic and political reforms in Ukraine. Henceforth, the Council of Europe and the EU played the leading role among international actors in the course of monitoring the protection of civil rights and political freedoms by various Ukrainian regimes. ${ }^{8}$

At various stages, the history of these relationships was rather dramatic. International organizations, such as the Council of Europe, the EU, and the OCSE, constantly criticized Ukraine for non-observance of its human rights obligations. This criticism encouraged and directed the activity of domestic change agents (human rights NGOs, independent mass media, political opposition, etc.). It can be emphasized that during that period Russia was not an alternative model, which would contrast the influence of European standards, since the Yeltsin administration was also more dependent on the West and at least partially oriented towards liberalizing market and political reforms.

Ukraine pursued the democratic anchoring to western standards through the ratification of fundamental conventions of the Council of Europe in the field of civil rights and political freedoms. However, this process was not smooth. Before the Orange Revolution the Verkhovna Rada ratified only 20 out of the 30 basic human rights conventions expected of Council of Europe members. The refusal to even formally endorse the remaining commitments can only be reasonably explained as a deliberate restraining of reform processes, chosen by the government and parliamentary majority at a time when anti-liberal elements in the Kuchma regime were powerful enough to block the submission of appropriate draft laws for ratification or even consideration. ${ }^{9}$

This situation caused constant anxiety in the Council of Europe. The resolution of the Parliamentary Assembly of Council of Europe (PACE) No. 1466 and the Recommendation of PACE No. 1722 of October, 5, 2005 noted that the new Ukrainian government had made progress in reducing the number of non-observance of human rights obligations, but it continued to delay the ratification of several important conventions in the field of the protection of human rights and was not carrying out the actions needed to resolve some questions in the area of practical realization of those already ratified.

Responding to evolving external pressure from international actors, President Yuschenko issued an Action Plan on the acceleration of the ratification process of the basic Council of Europe conventions in January 2006. The Plan envisaged the following measures: (a) the signature and ratification of Council of Europe Treaties in relation to the fight against corruption, human rights protection, and the strengthening of democratic institutions; (b) alignment of Ukrainian legislation to European democratic and human rights standards; and (c) effective implementation of European democratic and human rights standards by Ukraine (Edict of the President of Ukraine 39/2006). 
However, the continuing political crisis in Ukraine hampered any real progress towards the realization of this plan. Below we try to focus on major gains and mishaps in setting democratic rule of law standards in the area of civil freedoms and political rights in Ukraine.

\section{The new contents}

Ukraine's adoption of European standards of civil and political rights required not only formal rule adoption (for example, ratification of the Council of Europe conventions), but also essential efforts to ensure rule implementation and rule internalization. Hitherto, Ukrainian legislation did not recognize human rights concepts, such as the right to freedom and integrity of individuals; prohibition of torture and inhuman treatment; and the right to privacy. Moreover, from the very beginning, Ukraine faced a conflict between US and European models regarding the interpretation of the contents of civil and political rights. This was particularly evident in the fact that in the early 1990s change agents, such as third sector, oppositional politicians, journalists, mostly familiarized themselves with the US experience of democracy (thanks to various educational and information campaigns), and the idea that the USA was the best example of democracy for Ukraine was very popular. The US model promoted its legal and constitutional heritage as one of the prime sources of reference for universal civil and political rights standards to be applied in Ukraine. In addition, the US model put considerable emphasis on the role of the judiciary, consequently to the case law of the US courts, as a source of law making, which was not compatible with the civil law traditions existing in Ukraine (McFaul 2007).

On the other hand, the European model advocated the experience of specific European countries (France, Germany and the UK) and the European regional organizations (the Council of Europe and the EU) as a prime source of reference for civil and political rights for Ukraine. This situation caused certain difficulties for the new generation of Ukrainian judges, lawyers and politicians in applying US and European legal traditions in their everyday work. Ukrainian judges have been encouraged to apply the case law of the European Convention on Human Rights (ECHR) in their decisions. Therefore, in the end, the European model has prevailed due to the dominance of the Council of Europe and the EU vis-à-vis other international actors in Ukraine. The 'first wave of reforms' focused on the alignment of the Ukrainian Civil Code, Civil and Criminal Procedure Codes, information legislation, election laws, and the legislation on associations of citizens with best European standards. The reform of Ukrainian legislation took place in line with European standards. However, this influence was not uniform in every field. In some cases new Ukrainian legislation was inspired by relevant European legislation (Council of Europe, EU), while in other cases the Ukrainian legislation was influenced by Russian legal standards. For example, draft laws on peaceful assemblies submitted to the Verkhovna Rada 


\section{Roman Petrov and Oleksander Serdyuk}

in 1997-2004 were strongly influenced by comparable Russian laws. Even Ukrainian human rights NGO's were influenced by their Russian, rather than American or European counterparts. Indeed, the process of legal and institutional change in Ukraine in the last decade in particular has been a multilevel process, influenced by both liberal and illiberal external actors.

Moreover, even where formal rule adoption of Council of Europe and EU standards did take place, the Kuchma regime largely ensured that formal rule adoption was not followed by effective rule implementation. In fact, some of the new laws had provisions which did not improve, but worsened, standards of civil and political rights in Ukraine. For example, the new Civil Code of Ukraine contained regulations about unreliable information, which substantially interfered with the activity of the mass media and the implementation of the right to freedom of expression. The new Criminal Procedure Code, similarly, contained numerous drawbacks, which made possible arbitrariness and other infringements in law enforcement. Existence of these legal obstacles was used by the political opposition, and most actively on the eve of Orange Revolution as a proof of unwillingness of the Kuchma's regime to carry out the actual implementation of European standards into the Ukrainian political and legal systems. Hitherto, the most prominent international actors (the Council of Europe and the EU) still remain concerned about effective rule implementation of rule of law standards in the area of civil and political rights, even after the Revolution. International actors expressed their concern over the lack of decisive steps by the ruling political elite in Ukraine to reform the judicial system and the key democratic institutions, and that there was a delay in the ratification of human rights agreements and the arrangement of the national legislation and practice in accordance with them (Council of Europe 1466/2005).

An additional serious challenge to the process of the 'Europeanization' of Ukraine became the strengthening of the model of 'sovereign' or 'managed' democracy in Putin's Russia, which is characterized by a significant constrain of freedoms and related growth of authoritarianism. This model, which became a clear, open alternative to the European one, inspired Ukrainian veto players and hampered the strengthening of human rights protection at the expense of unhindered executive power.

\section{Abolition of the death penalty: the long search for a decision}

The fundamental right to life functioned as the 'litmus test' for Ukraine's place in international democratic society. This problem was on the periphery of the political legal discourse during the first years of Ukrainian independence, remaining a problem of moral, rather than legal value. For the first time the issue of the abolition of the death penalty became a subject of discussion during negotiations on Ukrainian membership of the Council of Europe. Abolition of the death penalty was recognized as one of the primary obligations, which Ukraine had assumed after joining the Council of Europe. Ukraine's delay in abolishing the death penalty led to a considerable increase in 
pressure from international actors (mainly again the Council of Europe) on the Ukrainian political regime. International organizations, by means of numerous programs of technical assistance and grants, encouraged change agents (pro-western political elites, which comprised opposition political parties and pro-western intellectuals) to accelerate the abolition of the death penalty through public opinion and educational programs. The Council of Europe issued resolutions criticizing the delay in the abolition of the death penalty in Ukraine. Pro-western members of the Verkhovna Rada of Ukraine (the 'European choice' bloc) decided to apply to the Constitutional Court of Ukraine with a request to recognize the death penalty as unconstitutional. After long deliberations the Constitutional Court of Ukraine decided to support this request. This decision led to the eventual ratification by the Verkhovna Rada of Protocol No. 6 (on interdiction of the death penalty) of the ECHR in April 2000. Among the post-socialist member states of the Council of Europe, Ukraine was the country where the abolition of the death penalty took longest. The decision to abolish the death penalty has happened due to the constant pressure of external agents (Council of Europe, EU). The political establishment in Ukraine was not ready to achieve this objective without an external pressure. In conclusion, one may argue that the influence of external actors on politics in Ukraine does not fully correspond to the Checkel's "socialization" process (see Checkel 2005). Instead, it was a more complex and multilevel process which reflected competing influences of external agents from the east and west of Ukraine.

\section{Freedom of expression and democracy 'watchdogs'}

Independent mass media and freedom of expression have a special value in the European model of democracy. The ECHR has recognized the mass media as a 'watchdog of democracy'. Unfortunately, freedom of expression became a key problem in relations between international actors (the Council of Europe and the EU, and - to a lesser extent - the USA) and the Ukrainian government during the authoritarian regime of President Kuchma. Starting from the mid-1990s the government directly or indirectly (through several oligarchic families close to President Kuchma) monitored the majority of key national mass-media groups: censorship existed in different forms, legal guarantees of independence of the mass media were essentially limited, and the state did not carry out any investigations of the murders of journalists. The practice of the destruction of the independent mass media by the judiciary became common. For instance, in 1999 alone 2,258 judicial claims against the mass media and journalists were considered by Ukrainian courts (Misyo and Petrova 2000). The opposition journalists Georgiy Gongadze and Ygor Alexandrov were murdered. It became obvious that freedom of expression in Ukraine was impossible without considerable reforms.

International actors' strategy to improve standards of freedom of expression used political and legislative tools. The Council of Europe and the EU issued political statements urging Ukraine to improve standards of freedom of 
expression in line with best western standards. Practically all PACE Resolutions established a deterioration of freedom of expression in Ukraine and demanded a response from the Ukrainian government. Moreover, the Council of Europe assisted the Verkhovna Rada in examining draft laws on the subject of compliance with European standards. In addition to these measures international actors provided considerable technical assistance in monitoring the situation over freedom of expression. This technical assistance resulted in the establishment of independent centers on human rights research, networking activities, and training. As a result of international actors' pressure, several important judgments, based on precedents of the ECHR, were issued in Ukraine, and this actually allowed a neutralization of the judicial mechanisms of influence on the mass media, and essentially increased the level of legal protection of Ukrainian journalists. For example, only 514 claims against the mass media, totaling 150,000 US\$, were submitted to courts in Ukraine in 2004. One should note that the quantity of claims against mass media decreased several times in the preceding years. ${ }^{13}$

The Orange Revolution became a turning point, giving hope for further radical changes to improve freedom of expression. However, these hopes had to meet political realities. Members of the new 'Orange' government gained a notorious reputation for being involved in actions aimed at limiting freedom of expression. In October 2005, PACE noted that freedom of expression reforms in Ukraine are rather slow and that the level of freedom of expression does not comply with recognized international and European standards (Council of Europe 1466/2005).

\section{The ECHR: a new engine for protecting human rights}

Since joining the Council of Europe as a member in 1995 the European Court of Human Rights (ECtHR) has enjoyed a significant influence on the development of the system of protection of human rights in Ukraine. Obviously, the ECtHR has been one of the most active external change agents for the past ten years (even if its judgments did not concern Ukraine). In the Sovtransauto-holding v Ukraine judgment in 2002, the ECtHR established the existence of serious violations of human rights in the Ukrainian legal system (absence of guarantees on protection of the right to property, and risks of intervention of the executive power in the activity of courts). In further judgments the ECtHR raised other important issues, which required serious legal reforms in Ukraine (Zhukovska 2004, 7-12). As a result of influence exercised by international actors such as mainly by the Council of Europe, the Ukrainian courts became more inclined to refer in their judgments to decisions of the European Convention on Human Rights (ECHR). This was especially notable in cases involving journalists and mass media as defendants at the suit of public bodies or civil servants. The ECHR's commentary on the meaning of Article 10 of the European Convention on Human Rights became the basis of the approach of Ukrainian courts in such cases, which played a principal role in the strengthening of freedom of speech. 
In conclusion, we highlight the fact that in the area of civil rights and political freedoms international actors, such as the Council of Europe, the EU, the Organization for Security and Cooperation in Europe (OSCE) and western democratic governments, especially the two most active governments, i.e. those of the USA and the UK, successfully achieved good standards in rule adoption of law. This goal was achieved through the anchoring to fundamental conventions on human rights and the provision of technical assistance to the Ukrainian judiciary. As a result, the new generation of change agents within the Ukrainian judiciary was formed: a part of the judicial corps, which successfully perceived the values of the European standards and started their implementation in the consideration of court cases and significantly influenced the rule adoption of civil rights and political freedoms. However, progress in rule implementation and rule internalization still is to be achieved.

\section{Judicial independence and capacity}

The need for a fundamental reform of the Ukrainian judiciary system has never been questioned. This is because both international actors (the Council of Europe, the EU, the OSCE, and some established western democracies such as the USA and the UK) and change agents (pro-western political elites, and members of political opposition) considered the Soviet model of the judiciary as a major impediment to the democratic rule of law and rule implementation, and rule internalization of democratic values in Ukraine.

\section{From the 'Soviet court' to ...?}

The foundations of judiciary reform in Ukraine were laid in the Concept of Judiciary Reform approved by the Decree of Verkhovna Rada of Ukraine in 1992 (Decree of Verkhova Rada of Ukraine 2296/1992). The Concept of Judiciary Reform called for the adoption of a number of framework laws on the reform of the judiciary system and legal proceedings in the course of the next two years, which "had to bring to life democratic ideas of justice developed by world practice and science" and to "ensure the correspondence of the judiciary legislation to international agreements ratified by Ukraine". Unfortunately, the goals of the Concept of Judiciary Reform were more ideological in their nature than legal. As a result, its implementation did not go further than enhancement of the independence of judges (judicial selfgovernment) and the creation of the system of specialized economic courts.

In fact, the Soviet-type judiciary was not significantly influenced by these cosmetic changes. Thus, the foundations of judicial procedures remained constant, as did the legal conscience of judges, and the whole system of lawenforcement agencies in Ukraine. Nevertheless, pro-Western political forces in Ukraine asserted the necessity of radical changes in society, though the directions of reforms were not precisely clear. The new political elites felt a 


\section{Roman Petrov and Oleksander Serdyuk}

sharp deficiency of constructive ideas concerning the reform of the judiciary. However, this gap started to fill in rather quickly. A number of western programs (governmental and non- governmental) targeted the diffusion of democratic values, the promotion of the best practices of western democracies with the aim of creating an efficiently functioning judiciary system in Ukraine. Two basic centers of western influence (the USA and Europe) have emerged. In practice, the geographical origin of such influences was not so important. However, these two different centers of influence entailed certain legal complications and contradictions for the evolving Ukrainian judicial system. The issue of diverse legal influences came to the top of the Ukrainian legal reform agenda when the Ukrainian government began negotiations to join the Council of Europe in 1992. At this time intensive internal discussion about the optimal model of court procedure and the judiciary system in Ukraine was launched. It was the first time that Ukrainian decision-makers had faced the rule adoption problem. Henceforth, change agents, such as political forces of pro-western orientation and, although partially, a few members of magistracy, contemplated which democratic examples are most suitable for Ukraine. The "third sector" in Ukraine was too weak yet to take full part in the discussion on these issues. The development of the new Constitution stimulated a search for the most appropriate models of justice, which could guide Ukraine to establish a modern and democratic judiciary. As a whole, the lack of institutionalization of international actors in Ukrainian society and the vagueness of democratic values led to a failure of those change agents to promote western democratic values in the Ukrainian judiciary at the time of adopting the new Constitution in 1996. Traditional judicial conservatism, hardened by the traditions of the Soviet court, prevented Ukrainian judges from appreciating these ideas and applying them in their practice.

\section{Legitimacy of the political regime of President Kuchma at the price of small judiciary reform}

The adoption of the Constitution of Ukraine in 1996 gave additional impetus to the reform of the judiciary. In November 1995 Ukraine obtained membership of the Council of Europe, which was accompanied by Ukraine's assumption of essential duties in the field of judiciary reform, in line with the Council of Europe standards. On the EU side similar requirements were specified in the EU-Ukraine Action Plan on Justice and Home Affairs (see Official Journal 2003). The Council of Europe Convention on Fundamental Rights and Freedoms, ratified by Ukraine in 1997, articulated the concrete scope of democratic freedoms and rule of law standards to be implemented by the Ukrainian government (for example, in a context of 'a right to a fair trial'). However, for the time being, these standards remain insufficiently enforced in Ukraine. Even pro-western change agents in the judiciary are insufficiently familiar with the scope of fundamental democratic standards and the means of their interpretation by the ECHR. 
In 1990s, the judicial reform in Ukraine was strongly influenced by Russia, where a parallel reform was enjoying a relative success. For the change agents, who were the supporters of the reform, the Russian "positive" experience was an additional argument in favor of the necessity to adapt best European judicial standards, taking into account the post-Soviet realities in Ukraine and in Russia, dominated by corruption and lengthy court procedures.

Subsequently, in the late 1990s Ukraine witnessed the emergence of an authoritative political regime associated with the former President Kuchma ('Kuchmism'). This situation constituted a main challenge to the judiciary reform at the time, characterized by the struggle of the executive power for total control over the judiciary system. Besides, one began to see the formation of powerful financial and industrial clans (oligarchic structures), which endeavored to control the judiciary in order to ensure smooth distribution and redistribution of state property to private hands. In particular, it caused the preservation of an independent system of economic courts in Ukraine, which have been influenced by mighty oligarchic clans and presidential power.

In such circumstances the problem of judiciary reform became a key issue in the conflict between the Verkhovna Rada and the President. ${ }^{14}$ President Kuchma vetoed and publicly criticized many draft laws on judicial reform, which were based on best standards of democratic court procedure and provided for the enhancement of court independence from the influence of executive power. Pro-presidential circles within the Verkhovna Rada prepared alternative draft laws containing mechanisms of direct or indirect influence of the executive power (already precisely personified by the presidential vertical of power) on the Ukrainian judiciary system.

At this time, international actors, such as the EU and the Council of Europe, consistently demanded the proper performance of membership duties by Ukraine through the adoption of democratic standards. Numerous programs of assistance to the Ukrainian government and civil society institutions in conducting the judiciary reform were realized jointly with international donors. As a result of consistent external support and pressure from the Council of Europe and the EU, the position of domestic change agents was strengthened. In this period the composition of change agents was rather mixed. Apart from a section of the judicial corps (primarily in national supreme courts), it included the representatives of the political elites (both in the Parliament and Presidential environment), who supported the pro-western orientation on the issues of reforming the legal system. However, this similarity in the positions of change agents was to a great extent not stable but pragmatic. The majority of domestic change agents openly joined the political opposition and various civil society institutions (representatives of the 'third sector', opposition journalists, and to a lesser degree, scholars and representatives of the public bureaucracy and judiciary). External assistance from international organizations (Council of Europe, EU, OSCE) and western democratic governments (USA, UK, Canada, Germany, the Netherlands) through the provision of financial and technical assistance with informational 


\section{2}

\section{Roman Petrov and Oleksander Serdyuk}

and educational programs, expert assistance, internships at the international organizations brought about successful rule internalization of democratic values among domestic change agents and enabled their association with the 'European democratic community'.

Further strengthening of the presidential power in Ukraine gave rise to serious concern among international actors. European organizations, such as the Council of Europe, the EU, and the OSCE, became most active and openly criticized the Ukrainian political regime. The US position was similar and was mostly realized by means of "implicit" political recommendations. On the eve of the presidential elections in 1999, the Parliamentary Assembly of Council of Europe (PACE) expressed "deep concern" over Ukraine's slow implementation of duties it had assumed as a member of the Council of Europe (Council of Europe 1179/1999a; Council of Europe 1194/1999b; Council of Europe 1239/2001a; Council of Europe 1244/2001b). European experts pointed out that since the adoption of the Constitution in 1996, the Ukrainian authorities "took no measures in the implementation of the judiciary reform". As a last measure the Parliamentary Assembly of the Council of Europe warned Ukraine about the possibility of "suspension of membership" (Council of Europe 1513/2001c).

In response to the external pressure of western governments (USA, UK and other western European governments) and international organizations (Council of Europe, EU, OSCE) the Verkhovna Rada adopted in June 2001 a set of ten laws - with the addition of a significant Law on Judicial Organization one year later - which were informally entitled "small judiciary reform". These laws inserted a few democratic novelties in the judiciary system in Ukraine: a uniform system of general jurisdiction courts headed by the Supreme Court of Ukraine; a new procedure of assignment and election of judges; the Supreme Council of Justice responsible for supervision of judges; more democratic system of appeal and cessation of judgments; better judicial control on legality of detention and arrest of persons, and on limitation of correspondence privacy, telephone conversations, cable and other communications (see Ogorodnik 2004). A direct link between these changes and the position of Council of Europe, which consistently supported the necessity of the judicial reform, can be easily seen. However, the main explanatory factor is still the will of the ruling political elite in Ukraine to preserve the (constitutional) legitimacy of the recent political regime, because the five-year term set by Constitution of Ukraine for the changes in the judicial system, was almost over.

On the whole, regardless of the motives of the political elites, these actions marked the beginning of the formation of institutional and administrative preconditions for a democratic judiciary in Ukraine. In addition, as mentioned above, the "small judiciary reform" was made because the consistent pressure from external actors. Thus, ultimately, the adoption of a rather cut-down variant of this reform with its discrepancies, inconsistencies and disregard of some important European standards, was a decision, which the ruling elite was forced to make, not only because of the pressure from the Council of Europe, but to 
avoid formal "unconstitutionality" of the regime before international actors and the international community.

\section{"In the end, the judiciary system needs to be reformed!"}

Although the "small judiciary reform" laid down the main institutional foundations of democratic judiciary in Ukraine, it was conducted in a rather incomplete way, both institutionally and procedurally. One could say that the general social efficiency of the judiciary system remained low. Moreover, it could neither function as a high-level democratic institution, nor avoid conversion into a functional appendix of the ruling political elite. Disapproval of the existing situation in the Ukrainian judiciary became the dominant topic of political debate between the ruling elite and political opposition. It became clear that the adoption of rule of law standards has not led to the elimination of 'Soviet judiciary' standards in Ukraine. The Council of Europe, the EU, and a few western democratic governments realized that utmost efforts has to be made to accelerate an effective rule implementation and rule internalization of western democratic standards inside the Ukrainian judiciary. International actors had to reassess the means of influence on the Ukrainian judiciary and to combine technical assistance with direct and indirect political pressure on members of the judiciary. ${ }^{16}$

As a result of international actors' influence, two wings of domestic change agents were formed. The first is the 'reformatory' wing, which consistently asserted the necessity of reforming the entire judiciary system in line with European standards of court procedure. Representatives of this wing championed the adoption of common European legal values, active social interactions with international actors in the framework of scientific exchange programs, trainings, conferences, and seminars. They advocated the enforcement of European legal standards and values through the application by Ukrainian courts of ECHR case law (according to some estimates, between 2002 and 2004 almost 1,000 judgments were issued taking into account judgments of the ECHR) (Zhukovska 2004, 18). In the final years of the Kuchma regime, the Supreme Court of Ukraine enjoyed more independence and freedom. This could be due to the fact that the Supreme Court maintains close international connections with the supreme courts of European democratic countries.

The second is the conservative wing, which was not in the majority but was able to hamper reformatory initiatives within the Ukrainian judiciary. Backed by the support of the conservative wing the Kuchma regime managed to subordinate the judiciary to its own interests on the eve of the Orange Revolution. This took place via the procedures of appointment of judges and the organization and financing of the judiciary system. However, due to the influence of international actors, standards of democratic court procedure and common European legal values have penetrated deep into the minds of Supreme Court judges, which led to their taking an active position in protecting democratic values during the Revolution. It showed itself in decisions taken by the Supreme Court of Ukraine during the 2004 presidential election 


\section{Roman Petrov and Oleksander Serdyuk}

campaign, especially in the decision of the third and final round of elections, when the grounds for it were not only a doctrinal interpretation of the corresponding Ukrainian law on elections, but also the explicit application of fundamental law of democratic principles.

In the aftermath of the Orange Revolution the new government did not take immediate actions to accelerate the reform of the judiciary system, which was explained as "lack of understanding of the problem by the new government". Society became discontented by the fact that political practice separated itself from the rhetoric of the Revolution period. Furthermore, in line with the best traditions of the old government the pressure upon judges continued, the practice of selection of judges among "acquaintances" remained unchanged, and higher public officials made incorrect comments and estimations of certain court decisions. Eventually, such practice undermined public trust in the new government. On 5 October 2005, the Parliamentary Assembly of the Council of Europe urged the Ukrainian government "to continue the reform of the judiciary in order to ensure its independence and effectiveness" (Council of Europe 1466/2005). As a result of growing external and internal pressure, President Yushchenko entrusted the National Commission on strengthening democracy and the supremacy of law with preparing the Judiciary Reform Concept in November 2005. This Commission comprised representatives not only of the Ukrainian government and non-governmental institutions, but also of international organizations (the OSCE, the Council of Europe, the European Commission and others). During the campaign for the parliamentary elections in March 2006 and also the anticipated elections in September 2007, President Yushchenko confirmed that the task of initiating the judiciary reform in Ukraine constitutes one of the top priorities for his party "Nasha Ukraina" and democratic forces in general. However, there was and there is no single understanding of specific directions of the judicial reform among democratic leaders and parties, which undedermines the perspectives of success.

In conclusion, we can highlight two approaches to judicial reform in Ukraine during the Kuchma regime. The first approach focused on the need to continue cooperation with European institutions in the field of judicial reform on the basis of pro-western democratic standards. The second approach prioritized the need to strengthen "administrative and controlling mechanisms in the judiciary" in order to gain control over the judiciary system from the executive. The 2001 Judiciary Reform Concept represented a compromise between these two approaches. On the one hand, there was the formal rule adoption of western democratic standards. On the other hand, veto players within the government managed to maintain "controlled courts" at their disposal. Thus, it became more advantageous to preserve the current situation than to accelerate rule implementation and rule internalization of rule of law standards by the judiciary in Ukraine. However, the changed political situation after the Orange Revolution led to the revision of the format of the judicial reform in Ukraine. In March 2006 the new Concept on Judiciary Reform was drafted. This 'Concept' targets the establishment of fair trial in Ukraine in accordance with best European standards. On the whole, the 
content of the new Concept corresponds to established values of the democratic court procedure, though the possibility of effective rule implementation and rule internalization of this Concept is under question. Within a few days of the issuing of the Concept, the Council of Judges of Ukraine requested President Yushchenko to suspend this process, because the consequence of its introduction could be the "destruction of the entire judiciary system". The issue was the conflict over specific institutional and administrative models of implementation of the Concept. In our opinion, ways to resolve this conflict will be defined not only by the relations between internal institutions and political forces, but also by the reaction of the Council of Europe and the EU. In early 2006, several programs of technical assistance to Ukraine, which were financed mainly by the European Commission and USAID, were initiated to reform the judiciary system,. These programs had two goals: (1) to create material pre-conditions for the reform (technical equipment of the courts, renovation of the premises, etc.), and; (2) to form public support for values of the reform. This had to provide not only formal democratic rule adoption, but also its real implementation in Ukrainian society. However, the contemporary political situation in the country became an obstacle to these reforms. Parliamentary elections in 2006 brought to power veto players led by the Party of Regions, As a result, progressive draft laws on judicial reform prepared by the President's secretariat are not likely to be adopted by the Verkhovna Rada, due to the lack of ideological and legal incentives, and the desire for counteraction by the Presidential power and political forces, united around the Prime Minister. Delay in realizing judicial reform in Ukraine resulted in the inability of the judiciary to resolve the constitutional crisis in April 2007. The Ukrainian judiciary was frequently used by either side of the Ukrainian political elite in the course of their political struggle. The Constitutional Court of Ukraine was pressed by all political powers to produce a decision on the constitutionality of the Edict of the President of Ukraine to disband the Verkhovna Rada in their favor (Edict of the President of Ukraine 264/2007a). Furthermore, in the course of exercising this pressure President Yuschenko dismissed two judges of the Constitutional Court of Ukraine without legal reason. In response to this situation the Parliamentary Assembly of the Council of Europe

deplore[d] the fact that the judicial system of Ukraine has been systematically misused by other branches of power and that top officials do not execute the courts' decisions, which is a sign of erosion of this crucial democratic institution. Independent and impartial judiciary is a precondition for the existence of a democratic society governed by the rule of law. Therefore, there is an urgent necessity for the Ukrainian political elite to carry out a comprehensive judicial reform, including through amendments to the Constitution. ${ }^{17}$

To conclude these two sections, reforms in the area of civil freedoms and political rights, as well as improvement of the judicial independence, give us 


\section{Roman Petrov and Oleksander Serdyuk}

grounds to argue that Ukraine has achieved a successful transition from authoritarian regime to hybrid regime. Suppression of freedom of expression and democracy underpinned by the declarative character of democratic and rule of law reforms during the period of Kuchmism entailed the emergence of the authoritarian regime in the pre-Orange Revolution era between 1991 and 2005. The decline of democratic standards in Ukraine was illustrated by the rigging of the first round of presidential elections in November 2004 and by the murders of opposition journalists. Popular disappointment combined with increasing pressure on the part of international actors and change agents caused a nationwide uprising, which led to the non-violent Orange Revolution and the triumph of Viktor Yuschenko in January 2005. Democratic reforms in the post-Revolution period resulted in the adoption of fundamental western democratic and rule of law standards by Ukrainian society. The independence of the mass media was strengthened, and the Ukrainian judiciary underwent reforms aimed at its independence, transparency and impartiality. In general, after the Revolution Ukraine was transformed into a more pluralistic and democratic society. The constitutional reform, which resulted from the Revolution, moved Ukraine from a presidential republic closer to a parliamentary republic. The political opposition obtained more confidence in expressing its own views and protecting its own rights. However, democratic reforms have not been completed to the point to consider Ukraine as a democracy. The Ukrainian political elite has not been able to ensure the full independence of the judiciary. The judiciary in Ukraine has been used to protect and promote political interests and objectives of both change agents and veto players. As a result, the judiciary in Ukraine has not been able to play a significant role in resolving the constitutional and political crises in 2007. In the end, the perspectives of reforming the Ukrainian judicial system remain undetermined because there is no unity in the understanding of objectives and actions within the change agents themselves.

\section{Reforms aimed at increasing institutional and administrative capacity}

Insufficient attention on the part of international actors (the EU) to the institutional and administrative capacity reforms led to a delay in democratic transition in Ukraine. In particular, this concerns the increase in the institutional and administrative capacity of legislative and executive powers. Before the Orange Revolution the legislative and executive became closely interrelated branches of power that served the interests of strong oligarch lobby groups. The legislative power gained a notorious reputation of being a nontransparent and closed institution where MPs serve their business interests. The executive became known for its corruption and nepotism. Turbulent changes in the civil service in the aftermath of the Revolution led to an immediate flow of qualified professionals from their positions. These people have been replaced by new individuals who claimed loyalty to the new 'Orange' government but who, in many cases, lacked impartiality and sufficient 
experience in public administration. As a result, the government faced a difficult dilemma - either to bring back the professionals to the civil service, disregarding their party preferences, or to improve the training of existing civil servants in line with best European standards. So far the government has tried to pursue both paths. The newly launched constitutional reform has been designed to accelerate these processes through: (1) improving the drafting, discussing and passing laws; and (2) administrative and public service reform.

\section{Improving drafting, discussing and passing laws in Ukraine}

The process of preparing and adopting draft laws in Ukraine resembles the legislative pipeline procedures in other European countries. However, there are drawbacks which seriously reduce the transparency of the entire legislative process. Veto players, that is, representatives of the bureaucratic elite and strong financial and industrial groups, created these drawbacks in order to keep the legislative process in Ukraine as non-transparent and non-objective as possible, in order to lobby for their political and business interests. The new political configuration of the Verkhovna Rada does not provide for final solution to these problems, because the interest of the dominant parliamentary forces in the "manual regulation" of the legislative process is growing.

Every draft law has to be scrutinized by the parliamentary committees of the Verkhovna Rada. However, decisions adopted by parliamentary committees on the legality of draft laws have the status of recommendations. This means that they are not binding for MPs, who can easily disregard recommendations proposed and act by means of consensus. This situation significantly strengthens the role of veto players, who can easily ignore the decisions of parliamentary committees in favor of own political interests. Especially, this situation inhibits the effective implementation of international democratic standards, such as the EU and Council of Europe acquis.

The possibility of public discussion of draft laws to be adopted by the Verkhovna Rada illustrates the bureaucratic inertia and strong influence of veto players (bureaucrats, politicians who lobby for the interests of powerful oligarch groups). Public discussion of draft laws is envisaged by Article 9 of the Law of Ukraine 'On Basis of the State Regulatory Policy in the Sphere of Business Activity' (1160/2003). This law allows everyone to present comments on a bill proposed for public discussion. Moreover the rules of Article 9 oblige the parties to take into account proposed comments while preparing a final draft law. However, only a limited number of bills can fall within these categories, which are "regulatory acts in the sphere of business activity". Thus, bills of other acts, which do not belong to the category of regulatory ones, are not being opened for wide public discussion.

On 3 January 2006 the constitutional amendments adopted in December 2004 came into force and significantly changed the political system in Ukraine. These changes gave more power to the Verkhovna Rada with regard to the appointment of the executive, and control over its activity. Besides, it is believed that the make-up of the parliamentary majority will render the 
process of preparation and law adoption more controlled and predictable. However, this can be accompanied by the limitation of the opposition's opportunity to influence the situation in the drafting of laws.

\section{Administrative and public service reforms}

The administrative reform that commenced in 1998 envisaged the application of measures aimed at increasing the effectiveness of state executive authorities in Ukraine. It was initiated by the Edict of the President of Ukraine 'On Measures for Implementing the Concept of the Administrative Reform in Ukraine' (Edict of the President of Ukraine 817/1998). The concept itself was developed by the State Commission on Administrative Reform in Ukraine a special advisory body that functioned under the President of Ukraine's office. This body closely cooperated with international actors, that is, more precisely the Council of Europe, the EU, and the OCSE, in order to conduct the administrative reform in line with best international and European practices. The reform pursued the following objectives: effective organization of executive power at central and local levels of administration; formation of a modern system of local self-government in line with European standards; protection of human rights and freedoms by the executive and local government; creation of a modern system of training and retraining of public employees; and the establishing of the efficient administrative system in Ukraine.

Since the Orange Revolution the objectives of the administrative reform have been revised and complemented with new objectives, such as transparency of public authorities, decentralization of governance, reform of law enforcement bodies, minimization of controlling functions of public bodies and increase of local self-government resources through territorial and budgetary reforms (Edict of the President of Ukraine 39/2006). The administrative reform was formally launched on 1 January 2007. The Council of Europe, the EU, representatives of western democratic governments and domestic change agents, such as pro-western political parties and pro-western political elites, hope that the administrative reform will enable decentralization of state regional administrations and, consequently, increase regional administrations' revenues through liberalization of tax legislation and adoption of the new Budget Code of Ukraine.

The first law on public service in Ukraine was adopted in 1993. This established the general framework for the organization and functioning of public service in Ukraine. However, this law, which has been amended several times, hardly allows the formation of a system of public service in line with European standards. European experts emphasized the following substantive drawbacks: vagueness of the scope of the legislation on public service, service; lack of clear regulation of administrative procedures; lack of clear and transparent rules for state employees' salaries (the main problem in this case being that the existing legislation considers a state employee's rate of salary as an insignificant part of their salary whereas at the same time all other parts 
of state employees' incomes are at the discretion of their manager and the award depends on subjective factors). Consequently, there is a lack of standards to assess the results of bureaucratic activity. Acknowledging the weaknesses of the law on public service, change agents initiated rule adoption and approximation of Ukrainian legislation on public service to European and international standards. Over several years, with the assistance of European consultative and expert programs, the government developed a new draft law on public service that was to be completed in detailed form and adjusted to European standards by the 'Code of Ethical Standards of Behaviour of Persons Authorized to Implement State Functions'. For this purpose, issues of the improvement of the quality of public service and enhancement of the procedure for appeals by individuals against public employees' actions were put at the top of the administrative reform agenda.

\section{Constitutional crisis (April 2007): a new call for institutional and administrative reform}

On 2 April 2007 the almost year-long confrontation between the minority 'Orange' coalition ('Nasha Ukraine', 'BUT') and the so called "anti-crisis" majority coalition ('Party of Regions', Socialist Party, Communist Party) culminated in an open constitutional crisis, when President Yuschenko issued an Edict to disband the Verkhovna Rada of Ukraine and to call new parliamentary elections in May 2007 (Edict of the President of Ukraine 264/2007a). The major motivation for this radical step on the part of the President of Ukraine was to terminate the "unconstitutional" transfer of MPs - members of the "Orange" coalition - to the "anti-crisis" coalition. However, the constitutional crisis provoked further instability in Ukraine and the division of Ukrainian people into the west and the east. The Verkhovna Rada did not recognize the legality of the Edict of the President and asked the Constitutional Court of Ukraine to consider whether the Edict complied with the Constitution of Ukraine.

In an atmosphere of escalating nationwide political crisis the Constitutional Court of Ukraine was expected to deliver a decision which had to be recognized by both parties to the conflict. For the second time since the Revolution, all members of the political elite in Ukraine expressed their readiness to accept the decision of the judiciary and not to continue the confrontation. However, due to the decision, expected by many experts, of the Constitutional Court in favor of the Verkhovna Rada, President Yuschenko exercised serious pressure on the judges of the Constitutional Court by dismissing two of them without legally justified reasoning. Further, President Yuschenko repealed the "expected to be unconstitutional" Edict from 2 April 2007, issued a new Edict on 26 April 2007 and called for a new postponement of the date of the parliamentary elections (Edict of the President of Ukraine 335/2007b). This decision ended all hopes of settling the conflict by legal means and risked further escalation of the political battle. 


\section{Roman Petrov and Oleksander Serdyuk}

Finally, after exhausting all legal and institutional means to settle the conflict and following active political mediation by the EU High Representative for the Common Foreign and Security Policy, Javier Solana, leaders of the opposing camps (President Yuschenko and Prime Minister Yanukovich) reached a shaky compromise at a private meeting on 4 May 2007 and agreed to hold new parliamentary elections in July 2007.

Several weeks later, after intensive consultations with representatives of all political parties, President Yuschenko set a new date for the parliamentary elections of September 30 th 2007. The constitutional crisis in April 2007 displayed several failures of the Ukrainian political elite. First, there was the inability of both change agents and veto players to solve continuing political confrontation by legal and institutional means. Second, there was the need to develop democratically functioning and respected institutional and administrative capacity of the legislative and executive in Ukraine in order to avoid further confrontations. Keen competition between the political forces, their irresponsibility and the fight for posts and authorities were the direct causes of the crisis. However, this explanation is not complete, since it had deep institutional roots as well. According to Council of Europe Parliamentary Assembly Resolution 1549, they were caused as a result of the incomplete constitutional reform of 2004, which came into effect at the beginning of 2006. From the very beginning European institutions paid attention to the fact that its provisions did not correspond to European democratic standards (such assessments were presented in detail in the conclusion of the Venetian Commission in 2004). A full proportional electoral system does not guarantee the representation of the interests of the whole people of Ukraine and may lead to a distortion of people's will. On the level of branches of powers the lack of an effective system of restraints and counterbalances gives grounds to political forces to feel their supremacy, in terms of the law as well. Even the principles of Constitutional Court formation are such as to make it dependent on political forces and individuals. The constitutional reform of 2004 took place as an internal process only. No external factors had influence over it and its logic was defined by the interests of the political elite only, which regarded it as a means of achieving their specific aims in the power struggle.

Finally, we would argue that enhancement of the institutional and administrative capacity (improving its transparency, observation of democratic and human rights standards) of the legislative and executive in Ukraine was not on the priority list of international actors, that is, of the Council of Europe, the EU, the OCSE, and western democratic governments. As a result, domestic change agents did not manage to create modern and efficiently functioning institutional and administrative capacity in Ukraine, which caused the sharp constitution confrontation in April 2007. Declared reforms have been limited by rule adoption, but omitted effective rule implementation and rule internalization. One can argue that for a long time after gaining independence Ukraine remained a hybrid regime with elements of autocratic and democratic government. However, the democratic reforms in the aftermath of the Revolution significantly raised democratic standards in Ukrainian society 
and pushed forward democracy in the whole governmental machinery. Thus, contemporary Ukraine approached the level of a country with solid minimal democracy. International actors, such as the Council of Europe, EU, and OCSE, acknowledged the results of democratic parliamentary elections in Ukraine in March 2006 and praised Ukraine's results in ensuring freedom of speech and media. However, serious work should be done to enhance democratic standards not only in Kiev and other big regional centers, but also in smaller regions so as to promote standards of democracy and good governance in Ukraine as a whole.

\section{Reforms to combat corruption, illegality and abuse of power}

The existence of corruption in Soviet society was publicly admitted during Gorbachyov's perestroika at the end of the 1980s. It was acknowledged that corruption is not an exception or atypical phenomenon in the conduct of officials, but a more systematic phenomenon, caused by serious problems in society. Therefore, after achieving independence Ukraine embarked upon overcoming the institutional causes of corruption. Romantic illusions about the possibility of eliminating this phenomenon by means of a "democratic choice" vanished rather quickly. Since the early 1990s, the Ukrainian government and political elites, that is, the leading political parties and representatives of business, endeavored to search for a pattern for an efficient anticorruption policy, optimum legislative tools and law-enforcement mechanisms. The first mention of corruption in Ukrainian legislation appeared on 16 December 1993 in the Law of Ukraine 'On Public Service' (Law of Ukraine 3723/1993). This law stated that a public official cannot "commit actions, which can be considered as a way of exploiting an official position in mercenary motives in his/her own interests, and also actions, which according to the current legislation are considered as corruption" (Law ofUkraine 3723/1993, part. 2, para. 5). Nevertheless, the provisions of this law became rather declarative since Ukrainian legislation neither defined the concept 'corruption', nor the actions that should be referred to as corruption or abuse of power. It happened because at that time neither members of the executive nor members of the legislature were aware about best western practices to combat corruption, illegality and abuse of power.

In this situation the best European experiences and corresponding political legal standards did not help domestic change agents very much, for two reasons. The first is that the formation of the Ukrainian pattern to fight corruption and abuse of power coincided with the process of formation of the relevant European standards. Only in 1999 did the Council of Europe draft and adopt two fundamental anti-corruption conventions (Criminal and Civil). ${ }^{18}$ The second reason is the absence of sustainable political will in Ukraine to apply best European and international standards to combat corruption and abuse of power. In the end, the Ukrainian government pursued imitation of anti-corruption activities in order to maintain positive cooperation with international institutions. 


\section{Roman Petrov and Oleksander Serdyuk}

\section{Anti-corruption legislation: hopes and disappointments}

Ukrainian anti-corruption legislation displays the complexity and discrepancy of the political and legal reforms in the 1990s. At this time corruption gradually became an inherent part of life in Ukraine. Neither the state nor civil society could find solutions and potential to tackle this problem. For the state it was the "fight against its own shadow", and civil society was in the process of post-totalitarian social transformations and was rather weak at that time.

The starting point for the development of the anticorruption legislation in Ukraine was the adoption of Laws of Ukraine 'On Fight Against Corruption' (Law of Ukraine 356/1995a) and "On Amendments and Additions to Some Legislative Acts of Ukraine in View of Adoption of Law of Ukraine "On Fight Against Corruption" in 1995 (Law of Ukraine 358/1995b). These laws are in line with general tendencies in the European post-socialist countries, where similar laws were also adopted in the same period. The Council of Europe agencies took an active part in drafting Ukrainian laws against corruption, granting consulting assistance, and examining the relevant projects. The Russian experience, where the initial conditions for the anti-corruption reform were almost identical to Ukraine, had the most evident influence on the drafting of Ukrainian anti-corruption legislation.

Ukrainian laws to combat corruption are rather repressive because they provide a uniform method of fighting corruption - bringing administrative (disciplinary) action against persons committing corruption offences. The prevention of corruption is limited to establishment of interdictions (limitations) concerning the actions of public officials and other persons authorized to fulfill functions of the state. The adoption of anticorruption laws became the subject of prolonged political disputes within the Ukrainian political elite at that time. In the end veto players managed to lobby for legal drafts of a rather repressive nature, rather than drafts of a precautionary nature. Such an approach was the reflection of an inclination to follow a repressive way of solving these problems, in line with the traditions of the Soviet criminal justice. It was this approach that was supported by the members of law-enforcement bodies imposing it on the political elites in the Verkhovna Rada. The absence of a clearly formulated alternative (in this period, in particular, the formation of general European anti-corruption standards was only just beginning), and also the interest of the presidential power to take some steps that would not pose a threat to the existing relationship, but would constitute some response to the needs of society, created the basis for the choice of the simplified repressive model.

As a result, the fight against corruption in Ukraine moved towards formalism. The government issued new laws and measures to combat corruption, but in practice the level of corruption did not change (Buromenskiy and Serdyk 2004a, 4-15). In other words, it became limited to reporting to law-enforcement agencies and bringing charges against representatives of the lowest rank of the state apparatus, such as secretaries of rural councils, for committing 
minor corruption offences. Very soon the imperfection of the anticorruption laws became obvious to many people, both in law-enforcement bodies and in Ukrainian society. Change agents initiated the drafting of almost 20 new anti-corruption laws in close cooperation with the Council of Europe and other international agencies. These draft laws did not fundamentally change the general approach to corruption control and related only to specific problems, which were, nevertheless, quite important. For example, there were proposals to extend the range of subject liability for corruption activity, to implement a mechanism of financial accountability of civil servants (avowal of receipts and expenditures). In this period the position of change agents was neither clearly formed, nor were they strictly identified. The initiators of the draft laws were members of the Verkhovna Rada and their content was fragmentary. It should be noted that in some cases even proposals to weaken anticorruption measures were adopted. However, these drafts were given a lukewarm reception by the veto players, who claimed that the new anticorruption laws looked exotic and did not correspond to Ukrainian realities. For example, experts in the field of criminal law rather actively denied any possibility of establishing criminal responsibility of legal persons for corrupt actions in Ukraine.

The issuing of the Council of Europe Criminal and Civil Conventions on corruption in 1999 accelerated the necessity to align Ukrainian anti-corruption legislation with best European practice. However, the veto players (political and business elites supporting the regime of President Kuchma) preferred immediate cosmetic changes rather than radical reconsideration of Ukrainian legislation. They could never accept the general approach to these Conventions, because it threatened the existence of the whole system of corruption relations, which were already formed on the basis of political institutions in Ukraine. That is why the political elites, united around the presidential power, became major veto players.

The Orange Revolution inspired further acceleration of anti-corruption law-drafting initiatives in Ukraine. Representatives of European organizations initiated political consultations with the new government on the improvement of Ukrainian anti-corruption legislation. Western donors launched new large-scale projects with this in mind in 2006. However, the new political elites, which supported President Yuschenko, did not support these initiatives, thereby acknowledging the conflict between further anti-corruption reforms and their political and business interests. Actually their position coincided with the attitude of veto players towards the tasks of reforming the anti-corruption legislation in Ukraine. Indeed, one of the first slogans of the Revolution, the separation of business from government, could hardly be implemented, since key figures in the movement endeavored to improve their business through the new government. Notorious corruption scandals in autumn 2005 , arising from the process of re-privatization and redistribution of state property, hampered anti-corruption activities and led to complicated results of parliamentary elections in March 2006 and the sudden ruin of the 'Orange' 


\section{Roman Petrov and Oleksander Serdyuk}

coalition in July 2006. The beginning of this crisis is attributed to public charges preferred by one of the coalition leaders, Alexander Zinchenko, against politicians from President Yushchenko's inner circle (O. Tretyakov, P. Poroshenko and others) when he pointed out their use of state positions to strengthen their private business, contrary to the public interest, using administrative pressure, corrupt lobbying and also favoritism.

These circumstances, the inefficient working of the Verkhovna Rada and the absence of the Constitutional Court raised serious doubts over the feasibility of adopting a new generation of anticorruption laws that could serve as a basis for the new strategy of fighting against corruption in 2006. However, the situation changed radically when the agreement between the President and political forces united around the Party of Regions was attained in August 2006. The Universal of National Unity was signed by representatives of all the ruling political parties in Ukraine (with the exception of the Communist Party) and provided support for the presidential package of anti-corruption laws. This package, attached to the Universal of National Unity, included the following legislative acts: ratification by the Verkhovna Rada of UN Anti-corruption Conventions, as well as Council of Europe Civil and Criminal Law Conventions on corruption; adoption of draft laws that aligned Ukrainian anti-corruption legislation with best international standards, i.e. a new framework law 'On Corruption Prevention Principles', the law on 'Amendments and Additions for Criminal Legislation and Legislation on Administrative Responsibility' and a landmark draft law for Ukraine on liability of legal persons for corrupt actions.

This package was submitted to the Verkhovna Rada in September 2006. However, it was not formalized due to the failure to form a united parliamentary coalition between pro-Russian political parties (the Party of Regions, the Socialist Party, and the Communist Party) and presidential forces (Party 'Nasha Ukraina' and 'BUT'). As a result, the parliamentary majority, which was formed on the basis of the Party of Regions, started to hamper the adoption of anticorruption laws. During the entire period when they were in power, veto players did not make any attempts in reforming the Ukrainian anti-corruption legislation.

\section{GRECO membership as major factor in enhancing effectiveness of anti-corruption activities}

In January 2006 the Ukrainian government and the Verkhovna Rada took major steps to reinvigorate the anti-corruption program through democratic anchoring. In particular, Ukraine ratified the Council of Europe Civil Law Convention on Corruption (ETS 173) and joined the Group of Countries Against Corruption (GRECO) in 2006. This meant that Ukraine fell under the GRECO control mechanism, which allows better implementation of European anti-corruption standards. However, the decision to join GRECO did not meet with universal approval in Ukraine. There were continuous discussions between members of the political elite concerning probable 
consequences for Ukraine, because real implementation of GRECO standards demanded radical changes to the entire Ukrainian legal system.

At the end of 2006 Ukraine was scheduled to go through the procedure of the monitoring of the progress of the national anti-corruption program. Obviously, for this purpose the Ukrainian government is endeavoring to accelerate the implementation of the anti-corruption program. Such steps were envisaged in the framework of the political agreement between President Yuschenko and the ruling political elite. Besides the abovementioned package of anti-corruption drafts, President Yuschenko approved by decree the National Program of Fight against Corruption 'On the Way to Integrity' in September 2006. However, practical implementation of this decree was blocked by the Party of Regions as a response to the failure of the negotiations to create the united parliamentary majority. This led to the dismissal of the anti-corruption laws package by the Verkhovna Rada. This situation demonstrates the weakness of the internal preconditions for the real implementation of European anticorruption legal standards in Ukraine (lack of clear position of change agents, public awareness, perception of value bases, etc.). At the end of October 2007 the official position of GRECO was published: it affirmed that Ukraine was behind in the actual implementation of the European anti-corruption standards. The reason of this was the continuing divergence within the Ukrainian political elite in understanding how to combat corruption in Ukraine and what kind of European experience is better to adopt and implement.

\section{Police reform and civilian control of the security forces}

The senior officers in the Ukrainian police and security services were raised and trained in the USSR. Therefore, the newly born Ukrainian police and security forces have inherited problems that were common in the vanished Soviet police system: low effectiveness; centralization and militarization; absence of civil control over law-enforcement; and non-correspondence of Ukrainian criminal legislation to international and European standards. However, the Ukrainian government decided to pursue gradual police reform, in line with best European standards and practice, in order to meet the criteria of membership of the Council of Europe. The EU and the Council of Europe encouraged a certain degree of policy reassessment and democratic anchoring within the activities of the police and enhancement of civil control over police and security. Hitherto, problems in rule internalization and embedding of democratic rule of law remain at the top of the police reform and civil control agenda. However, the progress achieved in these areas continues to be quite modest. This is because police reform and civil control never became top priorities in the EU-Ukraine relations and have been given secondary attention from international actors, including the EU and the Council of Europe.

Issues of the reform of justice, police and good governance are not covered by the EU-Ukraine PCA - the basic legal document in force, which regulates bilateral EU-Ukraine relations. Instead, attention to these issues has been 


\section{Roman Petrov and Oleksander Serdyuk}

limited to a few non-binding EU documents, such as the EU-Ukraine relations agenda in the EU-Ukraine Justice and Internal Affairs Action Plan 2001, the European Council Common Strategy on Ukraine 1999, and the EU-Ukraine Action Plan 2005. However, none of these documents provides serious impetus and comprehensive framework for substantial reform of the Ukrainian police and the enhancement of civil control over police and security. The 1999 European Council Common Strategy on Ukraine states that the EU supports Ukraine in all its efforts aimed at "properly functioning independent judiciary, a professional police force, the development of a meritocratic, well-trained public administration at national, regional and local levels are all key elements in the effective implementation of government decisions" (Article 10 of the European Council Common Strategy on Ukraine 331/1999). The EU-Ukraine Action Plan envisages training of the police in the prevention of ill-treatment and torture. ${ }^{19}$ The EU-Ukraine Justice and Internal Affairs Action Plan 2001 foresees exchanges of information and police cooperation between the Ukrainian police and police forces of the EU member states, as well as prevention of crimes, and training of Ukrainian police officers to the level of the EU. However, these documents scarcely tackle issues of low effectiveness, centralization and militarization, absence of civil control over law-enforcement, and non-correspondence of Ukrainian criminal legislation with international and European standards.

\section{Problems of effectiveness and civil control}

The number of police and security organs has grown immensely since Ukrainian independence in 1991 but they have not proved to be more effective. Since 1991 their number has increased seventeen-fold. As a result, the contemporary Ukrainian police and security force is bigger than the Ukrainian army. This means that there is one policeman per 120 citizens of Ukraine. At the same time, this increase in numbers has not brought with it an increase in Ukrainian police effectiveness in fighting constantly growing crime, especially organized crime.

The issue of civil control over police forces in Ukraine remained unresolved. In accordance with Ukrainian legislation none of the law-enforcement agencies can avoid civil control. Provisions of the Law of Ukraine 'On Democratic Civil Control over Military Units and State Law-Enforcement Organs' set a mechanism, which extends civil control to absolutely all the law-enforcement agencies (Law of Ukraine 975/2003a). Nevertheless, although the control system envisaged by Ukrainian law is comprehensive, the issue of the civil control effectiveness has hardly been improved. High profile criminal cases (the murder of opposition journalists Gongadze and Alexandrov) remain unsolved. The investigation process is insufficiently transparent to give the public appropriate information about the case. 


\section{Training of police officers and other law-enforcement agencies}

One of the reasons for the low effectiveness of democratic reforms in the Ukrainian police and security organs is the inadequate system of training of future police and security officers. Firstly, the system is based on Soviet military traditions, which did not teach to best European democratic practices. Secondly, the training of future and present police officers is carried out by military police academies and does not promote independent training (reform of curricula in line with European standards and participation of students in exchange programs abroad).

Specific educational establishments organized within the relevant lawenforcement agencies have a certain degree of initiative and independence. However, EU financial and technical assistance provide very little help for curriculum development in police and security educational establishments in Ukraine. As a result, there has been very little impact on the police academies in implementing new curricula on democratic rule of law. This system of education does not create change agents, such as pro-western senior officers and decision-makers among future police and security officers.

\section{Conclusions}

Table 7.1 displays the various factors that inhibit the process of rule adoption, rule implementation, and rule internalization of democratic rule of law standards in Ukraine. To conclude, we have set out a number of specific characteristics that lead us to believe that Ukraine enjoys a specific path in adopting western democratic rule of law standards. These distinguish Ukraine from other countries - the subjects of case studies in this book. The first characteristic is the geographical split of the country caused by numerous historical, ethnic and cultural disparities between the west and the east of Ukraine. This has far-reaching political consequences on the attempts by change agents to promote democratic rule of law reforms in Ukraine. It is because the west of Ukraine traditionally supports political parties with a clear pro-European orientation, while the east backs political circles which advocate reinvigoration of regional, political and economic integration in the post-USSR area under the leadership of the Russian Federation. That is why pro-western political parties usually play the role of change agents and pro-eastern political elite usually act as veto players in the process of rule adoption and rule implementation of western democratic rule of law standards in Ukraine.

The second characteristic is the vagueness of the EU external policy towards Ukraine. The EU pretends to play a leading role among international actors in exporting democratic rule of law values to third countries. Ukraine is no exception. Throughout the last decade the EU has skilfully applied the policy of conditionality in order to accelerate democratic reforms in Ukraine. However, while "welcoming European aspirations" the EU never promised 


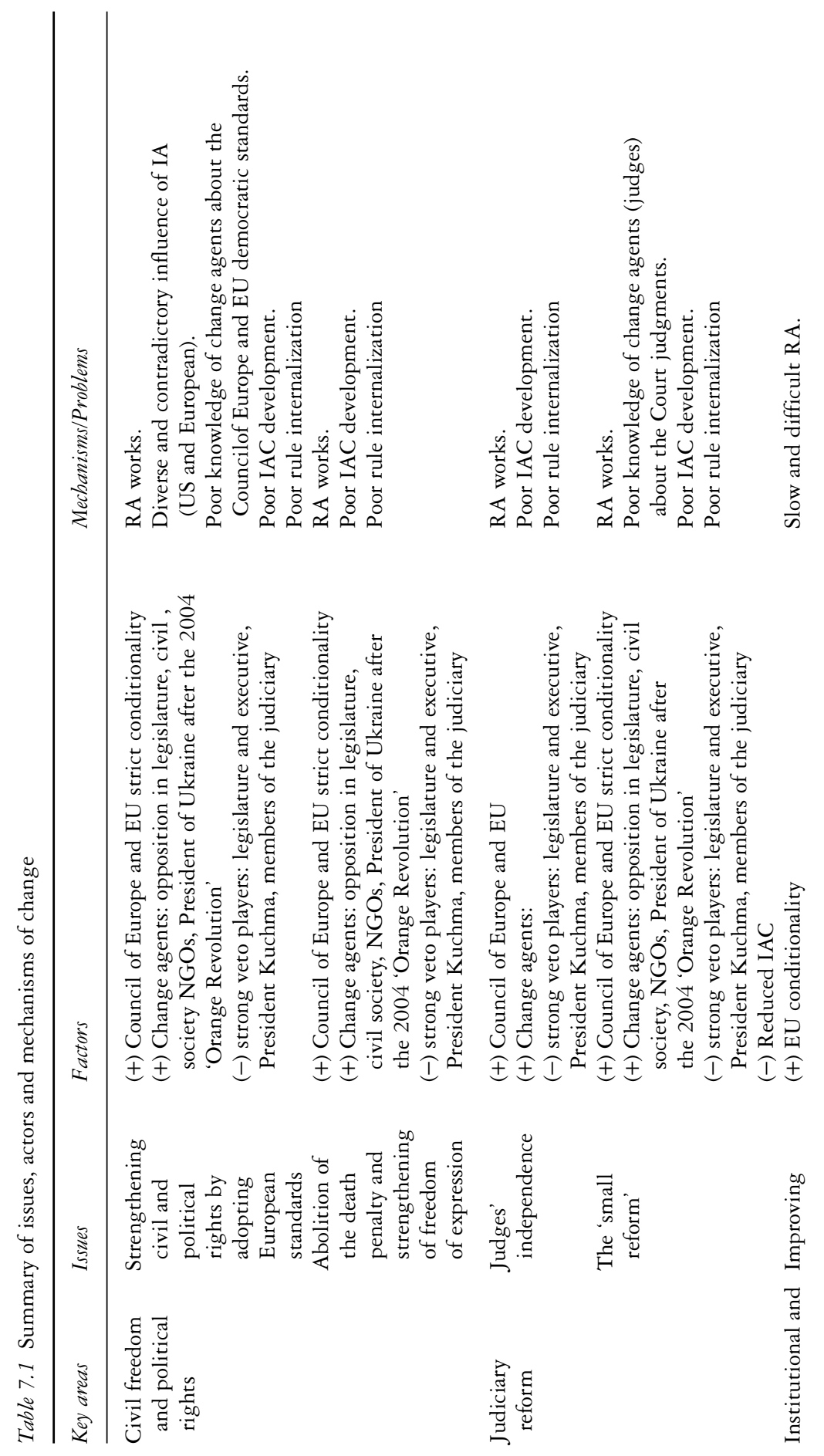


Ukraine: The quest for democratization 219
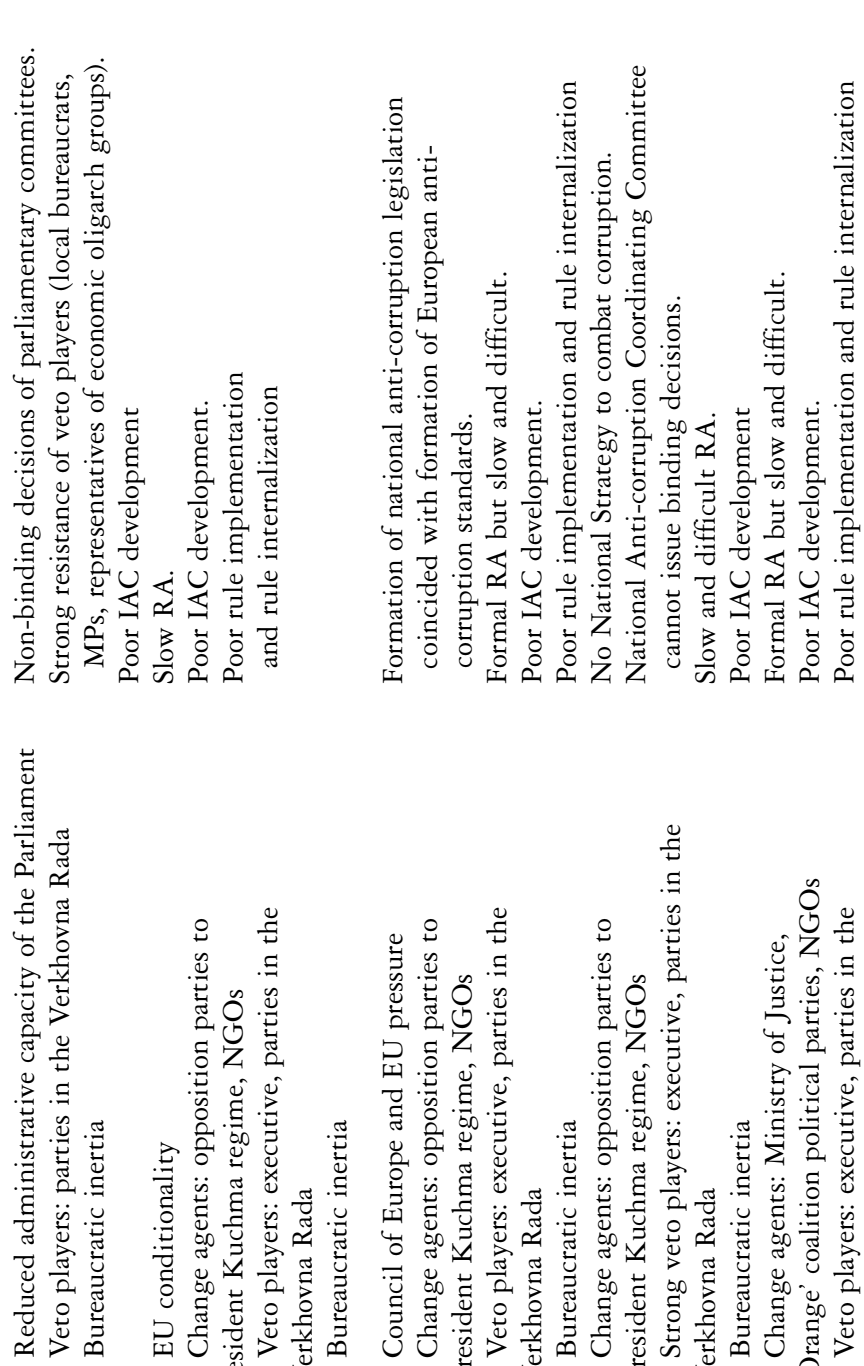

III

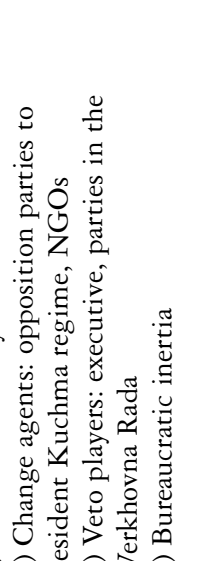

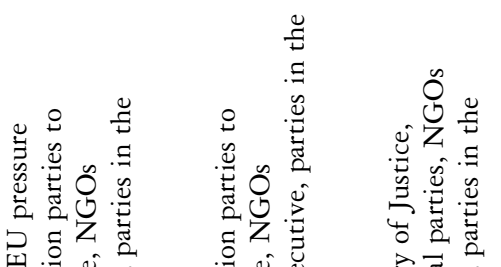

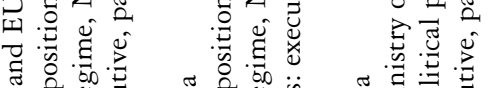

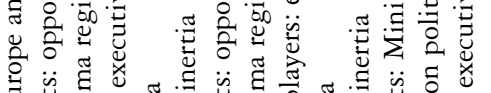

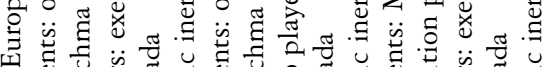

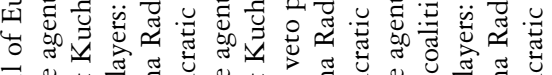

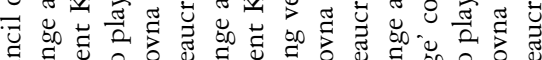

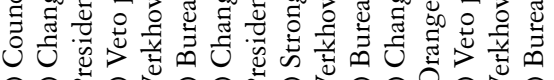

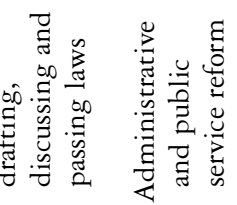

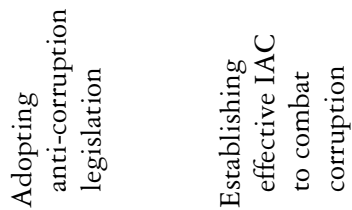

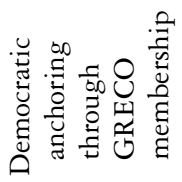

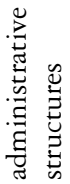<smiles>COCCO</smiles> 
220 Roman Petrov and Oleksander Serdyuk

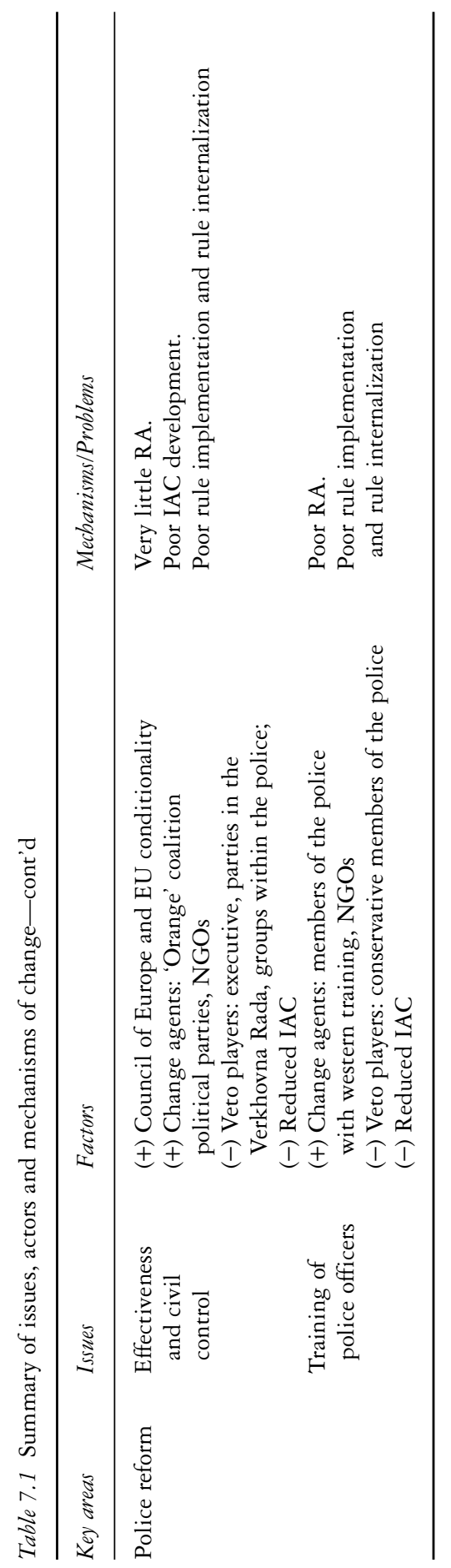


Ukraine the prospect of EU membership, justifying this policy by the need to absorb ten new members and to solve a turbulent internal constitutional crisis. Such an approach led to the weakening of domestic change agents visà-vis strong veto players. It could be argued that the European Neighbourhood Policy (ENP), devised as a substitute for full membership of the EU, brought modest results to both the EU and Ukraine. On the one hand, the ENP did not undermine the influence of the Russian Federation over Ukraine. On the other hand, ENP conditionality, without the prospect of full membership of the EU, did not justify the deterioration of Ukraine's relations with the Russian Federation, which led to painful conflicts over gas, meat and sugar between the two countries.

The third characteristic is the strong political and economic influence of Russia on the Ukrainian political elites. The densely populated Russianspeaking eastern regions of Ukraine enjoy historically close cultural and economic links with the Russian Federation. Most of the Ukrainian steel and machinery industry is experiencing considerable difficulties in accessing the highly competitive and protective European and US markets. Instead, they find valuable alternatives in the east. Pro-EU and pro-NATO aspirations in Ukraine might question the strength of Russian political and economic leverages in Ukraine. That is why the Russian Federation is keen to maintain its influence through powerful veto players (the anti-crisis political coalition and representatives of business) in Ukraine. The EU's adherence to the policy of conditionality without adequate economic 'carrots', on the one hand, and the relative openness of the Russian internal market to Ukrainian products, combined with soaring dependency on Russian energy sources, on the other hand, ensure the continuation of significant Russian political and economic influence in Ukraine in the near future.

Finally, we consider how the entire model of EUCLIDA has worked for Ukraine. In general, rule adoption proved to be very difficult for Ukraine. Strong veto players used their utmost influence to prevent rule adoption of democratic rule of law standards in order to maintain control over the judiciary and police force. Unfortunately, veto players managed to preserve their control over the judiciary and police in the time of Kuchmism and in the post-Orange Revolution period. In addition, rule adoption of democratic rule of law standards process was hampered by the contradictory and diverse influence of international actors. In particular, in the mid-1990s European and US international actors promoted their different standards in the area of the judiciary almost simultaneously, thereby causing problems in rule implementation and rule internalization of rule of law for Ukrainian change agents. A slow and difficult rule adoption took place in the fields of the reform of institutional and administrative capacity, combating corruption and police reform. The problems of adopting appropriate rules in combating corruption can be explained by the fact that the reform of Ukrainian anti-corruption legislation coincided with formation of European anti-corruption standards. Membership of the Council of Europe, combined 


\section{Roman Petrov and Oleksander Serdyuk}

with consistent EU conditionality towards Ukraine, led to successful rule adoption in the area of civil freedoms and human rights. After heated political debates, the death penalty was abolished and freedom of expression was enhanced.

The processes of rule implementation and rule internalization of democratic rule of law standards were not achieved at the desired level. In most cases, veto players (bureaucrats, extremist political parties, and the political elite supported by strong industrial and financial capital) torpedoed any progress of rule adoption. Moreover, poor rule implementation and rule internalization were caused by objective factors, such as the inadequate knowledge of members of Ukrainian judiciary about practice of the ECHR and the EU acquis. Unfortunately, international actors have not been effective in filling in educational gaps in the preparation of change agents within the Ukrainian judiciary and police force. There were also serious setbacks in institutional and administrative capacity. Change agents were hardly in a position to promote democratic rule of law standards, since key agencies set up as flagships of democratic rule of law reforms had no competence to issue binding decisions.

For the last decade the EU has advocated intensive anchoring of western democratic values in Ukraine. However, rule adoption of these values has not brought efficient rule implementation and internalization. One of the reasons is the fact that, hitherto, European integration has not become a widely accepted objective of political and economic reforms in Ukrainian society. For the time being Ukrainian political elites are unlikely to pursue further rapprochement with the EU at the expense of deteriorating relations with Russia. The Russian government has skillfully used Ukraine's dependence on energy supplies from Russia. As a result of the new Russian energy policy towards Ukraine, ordinary Ukrainians have experienced a sharp increase in their energy bills. On the other hand, the Ukrainian public realizes that other alternatives, such as closer integration with Russian and other CIS member states, could bring cheaper energy supplies and better access to less competitive eastern markets. Yet, by 2006 the ENP objectives had not become widely accepted as an appropriate alternative to CIS integration. As a result, there is no national consensus on the future of the pro-European policy in Ukraine. ${ }^{20}$ Nonetheless, the process of democratic rule of law implementation has achieved considerable progress in Ukraine, due to constant pressure from change agents and international actors. Fundamental democratic values have become a mandatory part of the programme of all the political parties in Ukraine. Change agents ('BUT' and the 'Our Ukraine Party') and veto players (the anti-crisis coalition headed by the Party of Regions) unequivocally endorse the pro-European foreign policy of Ukraine and need to continue implementation of common European democratic values. This leads us to conclude that the process of democratic rule of law implementation in Ukraine has indeed been developing along the lines suggested in the EUCLIDA model. 


\section{Notes}

1 Relevant information about the results of parliamentary elections in Ukraine could be found at the web site of the Central Electoral Commission of Ukraine <http://www.cvk. gov.ua> (last access: 22 October 2007).

2 For instance, immediately after signing the EU-Ukraine Action Plan the leader of the Communist Party of Ukraine, Symonenko, accused the EU of seeing Ukraine as an unequal partner. Instead, he urged Ukraine to accelerate economic integration with former USSR republics. See www.liga.kiev.ua (last access: 22 October 2007).

3 According to independent surveys 44 percent of Ukrainians support improving relations with Russia, 30 percent of Ukrainians support improving relations with the EU. Support for Ukraine's membership of NATO was expressed only 17.2 percent of Ukrainians. In the east of Ukraine 67.6 percent of those asked do not support Ukraine's membership of NATO. www.liga.kiev.ua (last access: 22 October 2007).

4 According to independent surveys, signing the EU-Ukraine Action Plan did not increase public support for Ukraine joining the EU. From May 2005 till now only 44 percent of Ukrainians support Ukraine joining the EU www.liga.kiev.ua (last access: 22 October 2007).

5 See below for details of the Ukrainian constitutional crisis of 2007.

6 Information from the web site of the Central Electoral Commission of Ukraine $<$ http://www.cvk.gov.ua> (last access: 31 October 2007).

7 See the Conclusions of the Parliamentary Assembly of the Council of Europe (Council of Europe 1995).

8 On this see the document on the Compatibility of Ukrainian Law and Practice with the Requirements of the European Conventions on Human Rights, Strasbourg, 2001 (HRCAD 2001, 4)

ED: Please check the reference list number.

9 European institutions were very concerned about the delay in the ratification of the key conventions, among them: Protocol No. 12 and No 14 for European Convention on Human Rights, European Social Charter, European Convention on Citizenship, European Convention on Trans-boundary Television, European Convention on Legal Status of Migrant Workers. Available at http://conventions.coe.int/Treaty/Commun/ListeTraites.asp? $\mathrm{CM}=8 \& \mathrm{CL}=\mathrm{ENG}$ (last access: 31 October 2007).

13 See Human Rights in Ukraine, No. 34 ( 2004, 4-11).

14 For details see the discussion on draft laws at the web site of the Verhovna Rada of Ukraine $<$ http://www.rada.gov.ua> (last access: 31 October 2007).

16 See the Resolution of the Parliamentary Assembly of Council of Europe on 'Implementation of its Duties and Obligations by Ukraine on Acceding Council of Europe' (Council of Europe 2003a).

17 On this our source is the provisional edition of the Resolution of the Parliamentary Assembly of Council of Europe 'Functioning of democratic institutions in Ukraine' (see Council of Europe 2007a).

18 See on this the Council of Europe Criminal Law Convention on Corruption on 1/07/2002 (Council of Europe 2002c) and Council of Europe Civil Law Convention on Corruption on 1/11/2003 (Council of Europe 2003b).

19 On this see article 2.1 (8) of the EU-Ukraine Action Plan. Recommendation No. 1/2005 of the EU-Ukraine Cooperation Council of 21/02/2005 on the implementation of the EU/Ukraine Action Plan. 14 The Centre of Economic and Political Studies, named after Razumkov <http://www.uceps.org/eng/show/335> (last access: 14 November 2007), conducted a survey on the eve of parliamentary elections in Ukraine in March 2006. Results showed that 42.2 percent of respondents were in favor of prioritizing relations with the Russian Federation over relations with the EU. Only 25.4 percent of respondents prioritized developing relations with the EU. At the same time 61.4 percent of respondents were against joining NATO and 40.7 percent wanted Ukraine to obtain full membership of the EU. 